Article

\title{
“To Sing with the Spirit:" Psalms, Hymns and the Spirituality of Late Eighteen Century American Presbyterians
}

\author{
William Harrison Taylor
}

Alabama State University, P.O. Box 271, Montgomery, AL 36106, USA; E-Mail: wtaylor@alasu.edu;

Tel.: +1-334-229-8536

Received: 1 November 2013; in revised form: 6 December 2013 / Accepted: 9 December 2013 /

Published: 11 December 2013

\begin{abstract}
This paper contends that the contemporary discussion among theologians regarding the relationship between theology and spirituality can offer new insight into the eighteenth century religious world. This theological discussion has wrestled with, among other things, the questions of whether theology and spirituality are mutually exclusive and what exactly their relationship looks like. Resoundingly, theologians such as Alister McGrath, J. I. Packer, and Sandra Schneiders have concluded that any separation of the two represents a false dichotomy within Christianity. Accordingly, Christians are called to "the quest for a fulfilled and authentic Christian existence, involving the bringing together of the fundamental ideas of Christianity and the whole experience of living on the basis of, and within, the scope of the Christian faith.” Sound theology, then, necessitates living by the Spirit and vice versa. The benefit of this theological position for religious history lies in its reevaluation of the common categorization of Christians as either theologically or spiritually focused. By heeding the call of contemporary theologians and blurring these lines of distinction, historians can afford eighteen century American Christians the chance to better define themselves. Considered in this light, the actions of the Presbyterians, for instance, are freed from the manipulative "social control" framework as one of the "establishmentarian” churches. Instead, the Presbyterians reveal characteristics generally reserved for the democratically charged "sectarians," such as a robust spiritual life compelled by music.
\end{abstract}

Keywords: Presbyterians; eighteenth-century; psalmody; hymnody; spirituality; music; theology; America 
In 1793, the events of the ecclesiastical trial of the reverend Adam Rankin spilled over from the Presbytery of Transylvania to the public sphere. This ordeal had plagued the regional ruling body since 1789 and, when all was seemingly finished, the dismissed Rankin brought his case to the American reading public. When the presbytery followed Rankin into the public sphere, they brought numerous witnesses including the respected Samuel Blair and David "Father” Rice. Rankin opposed the psalms and hymns of Dr. Isaac Watts to the extent that he deemed any who supported them as rank deists and he refused to either officiate or share communion with the offenders. This happened to include most of Rankin's fellow ministers in the Transylvania Presbytery and the overarching Synod of Philadelphia and New York. What was equally troubling for the ruling body was that Rankin was also reported to have gotten these disturbing directives by divine revelation. Rankin allegedly stated, "That the divine being had raised him up as an instrument to overthrow the use of Dr. Watts' psalmody in the church, and that he would live to see the day, that he himself would do it ([1], p. 4).” However, it was only after Rankin began "forming separate societies” during the four year disciplinary process, that the presbytery finally dismissed him "not merely for the things proved against him, at his trial, but for these, his schismatical proceedings deposed him ([1], p. 14).” Sensitive to both the church's position in the public sphere and the tumultuous spirit psalmody could arouse, the presbytery thoroughly countered Rankin's accusations and defended their decision to remove him from the ministry.

For a modern audience, this episode has a tendency to appear satirical or worse, indicative of the unenlightened activities of the nation's religious forbearers. Yet, Adam Rankin's story is not the solitary thread in this Presbyterian narrative, and it is far from the first, with other tales dating as far back as 1753. Also, without delving too far into what C. S. Lewis called, "chronological snobbery,” it will suffice to say that the modern American religious world is still pestered by problems of music ([2], pp. 206-07). However, the problems encountered both now and in the eighteenth century, largely relate to music's role in Christian spirituality. Interestingly, and keeping in view the anachronistic dangers, the contemporary discussion among theologians can offer new insight into the eighteenth century religious world. This current scholarship, sparked by the popularly renewed emphasis on Christian spirituality within churches, has wrestled with, among other things, the questions of whether theology and spirituality are mutually exclusive and what exactly their relationship looks like. Resoundingly, theologians such as Alister McGrath, J. I. Packer, and Sandra Schneiders have concluded that any separation of the two represents a false dichotomy within Christianity [3-6]. Accordingly, Christians are called to "the quest for a fulfilled and authentic Christian existence, involving the bringing together of the fundamental ideas of Christianity and the whole experience of living on the basis of and within the scope of the Christian faith ([3], p. 2)." Sound theology, then, necessitates living by the Spirit and vice versa.

It is, in part, the contention of this paper that this theological understanding offers invaluable insight to religious historians. This is not to say that historians have overlooked either the doctrinally driven or the spirituality driven Christians. Any cursory examination of the literature will show otherwise. The historiography of the late eighteenth century American religious world, for example, is well stocked with excellent studies of all denominations from the more established to the more democratically oriented. No, the benefit of this theological position for religious history lies in its reevaluation of these common categorizations of Christians as either theologically or spiritually focused. By heeding the call of contemporary theologians and blurring these lines of distinction, historians can afford eighteen 
century American Christians the chance to better define themselves. Considered in this light, the actions of the Presbyterians, such as those of the Rankin episode, are freed from the manipulative "social control" framework as one of the "establishmentarian" churches. Instead, the Presbyterians reveal a more complex Christian spirituality comprised of characteristics generally reserved for the democratically charged "sectarian" churches, such as a robust spiritual life compelled by music [7-12]. ${ }^{1}$

The role that music played in the development of the eighteenth century Presbyterian Church's spirituality is, in part, revealed in the many controversies surrounding music that troubled the denomination at this time. The concern of psalmody is first noted in the minutes of the Synod of New York in 1753 when the ruling body was introduced to the problem tearing at the congregation in New York City. ${ }^{2}$ In particular, the issue revolved around whether it was appropriate to sing from Dr. Isaac Watt's Psalms of David Imitated during congregational worship. Watt's version was markedly different from the 1650 version crafted by Francis Rouse, which had been favored among the Scottish Presbyterians and among their own American forefathers. Change was not a problem in and of itself, especially not in a New Light congregation, but Dr. Watts' work was seen as a human interpretation of divine songs, as opposed to the translation of the psalms the church had enjoyed previously. At the heart of this crisis then was not a narrow-minded problem with semantics but, rather what was seen as a fundamental issue of spiritual motivation — whether Watts' work was of the Holy Spirit.

To address this problem the synod enlisted some of their best ministers in the persons of Samuel Finley, Charles Beatty and Samuel Davies ([13], p. 252). ${ }^{3}$ Quickly, the committee engaged the situation and presented their recommendation to the synod and to the New York congregation. Since the church had been only using the Watts version before the crisis, the committee suggested that the church continue to sing Watts' psalms "lest the animosities in the congregation should be more inflamed, but they most earnestly recommend moderation, forbearance, and condescension to both parties, till such time as by the use of proper measures, they shall come to an agreement among themselves ([13], p. 252).” Peace, it seemed, was restored, but it proved short-lived. Two years later, in 1755 , the same congregation brought the case again before the synod, and as the number of members

1 Some scholars use the terms "Standing Order" and "Religious Newcomers" in place of, respectively, "Establishmentarianism" and "Sectarian." Much of the religious history focused on the late eighteenth-century forward can be divided into two schools of thought that center on the "social control" hypothesis. Those who support this argument contend that this period is marked predominantly by the clergymen trying to retain their control over the common person. Although the "social control" thesis was the historical interpretation for a number of years, recent historians, such as Nathan Hatch in his Democratization of American Christianity have attempted to counter it by rewriting the history of the Second Great Awakening. As a result, churches during this period fall into one of two categories: the "religious newcomers"- the Methodists, Baptists, Mormons, African American Christians and the Christian Churches_and the "Standing Order"-the Congregationalists, Presbyterians or Anglicans. For these historians the "religious newcomers," inspired by the democratic impulses of American Revolution, were the true catalysts for the Second Great Awakening as their egalitarian principles sparked the Christianization of Americans, the Democratization of American Christianity, and the Democratization of America in general.

2 Between 1740 and 1758 the American Presbyterian Church was divided into two synods, the Old Light Synod of Philadelphia and the New Light Synod of New York. In 1758 the church was reunited under the Synod of New York and Philadelphia.

3 Not only did all three ministers serve key roles in the various ruling bodies of the Presbyterian Church, but both Samuel Finley and Samuel Davies also served as President of the College of New Jersey (now known as Princeton). 
wishing to sing the "Scotch version" had noticeable increased, the synod decided that "the Scotch version be used equally with the other in the stated public worship on the Lord's days." Again, the ruling body reminded the church that "mutual forbearance and condescension in such cases, is a duty which Christians owe to one another, and is necessary to preserve the peace of society ([13], p. 267).”

When the Synod of New York reconvened in May 1756 it was met with yet another letter from the congregation, but this time the tone had changed. In their decision, the ruling body noted the paper "contains insulting and even threatening expressions, and insinuations of partiality and dishonesty, together with several demands proposed in a very disrespectful manner, and with an air of contempt." No doubt finding it difficult to muster Christian charity, the synod bluntly wrote to the congregation that "the singing of Dr. Watt's version of the Psalms" was permissible and that it was the "conduct of the congregation" in this matter that had prompted the ruling body to act "for the sake of their peace." Because this situation had spiraled out of control and threatened the fabric of the church, the ruling body "determine that this judgment shall be finally decisive as to this affair ([13], pp. 274-75)." Perhaps the ruling body suspected the specter of Watts' spirituality would further haunt the denomination, but for the moment it had been subdued. As troublesome as this affair was for the synod, it demonstrated that Presbyterians were fiercely concerned with what motivated them during their divine worship, and although they brought different methods, both believed they were driven by the Spirit.

After seven years, psalmody reared its troublesome head again in 1763, but by this time the Synod of New York had reunited with the Synod of Philadelphia to form the Synod of New York and Philadelphia. Despite the union, there were still clear tensions between the Old Lights and the New Lights within the denomination and highly charged issues, like that of psalmody, had the potential to rend the church anew. Fortunately, when the matter was raised in 1763 it was in the form of a question from an unnamed congregation, which relieved some of the pressure on the ruling body. Instead of creating a committee, the synod uncharacteristically, placed the responsibility on all the representatives therein to read Watts' psalms and reach a conclusion. However, until a decision had been reached the ruling body wrote, "The Synod have no objection to the uses of the said imitation by such ministers and congregations as incline to use it, until the matter of psalmody be further considered." This consideration would last two years and "after much discourse on the subject" in 1765, the "Synod judged it best ... only to declare that they look on the inspired Psalms of Scripture, to be proper matter to be sung in Divine worship, according to their original design and the practice of the Christian churches, yet will not forbid those to use the imitation of them whose judgment and inclination lead them to do so ([13], pp. 331, 338 and 335).” Psalmody alone was still the rule for public worship, and following the precedent set in 1756, no version was adopted or championed over the other because both versions of "the said Psalms are orthodox, and no particular version is of Divine authority ([13], p. 275)." Orthodoxy decided their fate, which meant the question of Watts' became a question of Christian liberty, and in that arena the ruling body claimed no authority.

The Presbyterian understanding of orthodoxy, including the concept of Christian liberty, was grounded firmly within the seventeenth-century Westminster Confession of Faith. Contrary to the fashion of the eighteenth-century Anglo-American religious world to downplay, to the point of avoidance, doctrinal and creedal distinctions, the American Presbyterians repeatedly confirmed, although not always unanimously, their adherence to the work of the Westminster Divines. 
Accordingly, the Presbyterians believed that "God alone is Lord of the Conscience, and hath left it free from the Doctrines and Commandments of men, which are in any thing contrary to his Word . . . So that, to believe such Doctrines, or to obey such Commands out of conscience, is to betray true Liberty of Conscience ([14], p. 35).” For the Presbyterian leadership the issue of psalmody was an issue of Christian liberty, and as such they could not constrain the consciences of their congregations. It was only by respecting and preserving this liberty that Christians could properly relate to fulfill their divine purpose and the Presbyterians had no interest in further hindering the cause of Christ.

The clear assertion of Christian liberty by the synod in 1763 brought eight years of silence on the issue of psalmody, but like the dreaded smallpox outbreaks, the threat of the next crisis hung over every new year. When the Second Presbyterian Church in Philadelphia submitted questions concerning the use of Watts' in 1773, the synod created a committee which included both the influential Dr. John Witherspoon and Dr. John Rodgers. Acting quickly, the committee again recommended that previous synod decisions be upheld "which countenance congregations in determining this matter according to their own choice.” Because this was an issue of Christian liberty both the committee and the full synod stated that "they cannot make any order to forbid the congregations to continue the practice" and that "the Synod on this occasion think proper earnestly to recommend to both parties peace and harmony, and to forbear all harsh sentiments and expressions, and in particular that neither of them intimate that either of the versions in question is unfit to be sung in Christian worship ([13], pp. 448-49).”

In the following years, concerns of psalmody were replaced by those of war. In 1785, in the midst of post-war rebuilding, a motion was passed calling for the synod "to take the assistance of all the versions [of the psalms] in our power, and compose for us a version more suitable to our circumstances and taste than any we yet have ([13], pp. 513-14)." A new committee was formed comprised of Dr. Patrick Alison, Dr. Robert Davidson, Dr. John Ewing, Mr. Samuel Blair, and Mr. Timothy Jones. After two years of work, the synod approved the committee's suggestion that the recently edited and expanded version of Watts' psalms by Joel Barlow become the recommended version to "be sung in the churches and families under their care ([13], p. 535).” Again, the synod clarified that this was their recommendation, and not an order. Whether the ruling body was prompted to act by rumors of renewed controversy is unclear, but what is certain, is that the 1787 decision came too late to avoid the Abingdon riot.

Reports of the uprising within one of their presbyteries reached the synod in 1787 and they were greatly distressed to "find one source of uneasiness in addition to what had been mentioned in their country, and among themselves, was about psalmody.” This question of spirituality had moved beyond a war of words and had manifested itself in physical conflict. To be sure, there were also other issues motivating the riot, such as the "political differences in that part of the country," but the danger related to psalmody had undeniably increased. The synod pleaded with the Abingdon churches, "in a spirit of Christian love, to forgive one another, and bury in oblivion all that had passed." In a pastoral letter to all of their churches across America, the ruling body emphatically stated, "the Synod do highly disapprove of, and condemn all such tumultuous and riotous proceedings.” Taking advantage of this opportunity they reiterated that all congregations had right to choose which psalms they sung and "they are far from disapproving of Rouse’s version, commonly called the Old Psalms.” "[E]ither may be used by the churches," the synod wrote, "as each congregation may judge most for their peace and edification." And as they believed this still to be an issue of Christian liberty they "therefore highly 
disapprove of public, severe, and unchristian censures being passed upon either of the systems of psalmody, and recommend it to all ministers in those parts of the Church, to be more tender and charitable on these heads ([13], p. 537).”

When the aforementioned troubles surrounding Adam Rankin surfaced in 1789 and continued to 1793, the various ruling bodies, including both the Presbytery of Transylvania and the newly formed General Assembly ${ }^{4}$ were remarkably patient. The General Assembly implored Rankin "and endeavored to relieve his mind from the difficulty he appears to labour under.” Yet still he charged the ruling body with "a great and pernicious error, in the public worship of God, by disusing Rouse's versification of David's Psalms, and adopting in the room of it, Watt's imitation.” Attempting to respect Rankin's liberty of conscience the General Assembly "only recommend to him that exercise of Christian charity towards those who differ from him in their views on this matter, which is exercised towards himself; and that he be carefully guarded against disturbing the peace of the Church on his head ([15], p. 182).” His failure here and his efforts to foster dissension within the denomination forced the presbytery to dismiss him.

Yet, if the dangers were as real as the series of events from 1753 to 1789 indicates, it begs the question of why the Presbyterian leadership held their position regarding psalmody and continued to tolerate the intolerant in their midst. In part, the answer can be found by applying the arguments of historians such as J. C. D. Clark and James Bell, that Americans were chiefly concerned with preserving orthodoxy even if that meant war, as they argue, or not violating the doctrine of Christian liberty as shown here $[16,17]$. However, there is more to glean. Also tied to their notion of orthodoxy was the necessity of singing praises to God. This formed an unmistakable part of divine worship for Martin Luther, John Calvin, John Knox and the Westminster Divines; all of whom laid the foundation for what the eighteenth century American Presbyterians believed. Well known were the stories of Protestants whose tongues were severed to keep them from singing the psalms on route to and while they burned at the stake ([18], pp. 35-39). If those tales were not evidence enough, the American Presbyterians could rely on their own recent history to illustrate the tremendous power of music. Its capacity to inspire, fortify and edify Christians far outweighed the potential dangers it might arouse.

Disputed psalmody was not the only ghost to disturb the Presbyterian peace. During the 1750's both the Old Light and New Light synods came to see themselves as divinely tormented for their earlier schism. Richard Treat wrote, on behalf of the Synod of New York, "We have been warned and chastised, first more gently, then more terribly; but not returning to him that smites us, his anger is not turned away, but his hand is stretched out still. Judgment yet proceeds, the prospect becomes darker and darker, and all things respecting us are loudly alarming ([13], p. 276).” Their divine punishment was the French and Indian War, and it pushed the factions towards reconciliation, which was realized in 1758. Central and intertwining themes of this reunion were the church's interdenominational mission and its efforts to "take heed to our Doctrine, that it be not only orthodox, but evangelical and spiritual, tending to awaken the Secure to a suitable Concern for their Salvation and to instruct and encourage sincere Christians.” They were determined to not only work more charitably with each other within the church, but also with all the various Christian denominations that comprised the body of

4 The new national ruling body, the General Assembly, was the result of a massive restructuring of the Presbyterian Church in 1788. 
Christ. This was a vow to consider themselves and their actions as a part of the body of Christ ([13], pp. 285-88). The Presbyterians were submitting themselves to their fellow believers. As Christians they were equals and dependent on one another for success.

Music was one of the primary tools the Presbyterians relied on to fulfill these reunion goals, especially those of interdenominationalism. Exemplary of this spirit was the reverend Samuel Buell, who befriended and championed the first Native American to be ordained in the Presbyterian Church, Samson Occom. While petitioning in the colonies for money, books, and hymns to support Occom's mission among the Oneida, Buell used his gift for song to inspire his fellow colonists to contribute. In a letter to a potential patron, which was eventually published, Buell's excitement over the cooperative and missionary possibilities prompted the minister to end his letter with a song:

King Jesus reigns, and spreads his glorious Fame, The savage Nations know, and trust his Name; Triumph ye Saints! Ye Angels strike the Lyre! In everlasting Praise, let all conspire ([19], p. xv)!

Buell quickly apologized, "Dear Sir, I forget myself, the pleasing Theme has transported me beyond the Limits I had prescribed to my Mind," but the joy that this Presbyterian felt was obvious and it is no small matter that he chose to express himself through song. It was his "hope . . . that we shall see Christians, though in some lesser Matters of differing Opinions, agreeing harmoniously in this truly generous, interesting and important Work, contributing liberally toward promoting the Propagation of the glad Tidings of Salvation among the Heathen ([19], pp. xiv-xxv).” Even when not singing, Buell called on musical imagery to prick the consciences of his audience when he describes the cooperation as "harmoniously."

Buell was not alone in this regard. In 1774, Samson Occom joined those employing music for the benefit of Christendom when he published, A Choice Collection of Hymns and Spiritual Songs; Intended for the Edification of sincere Christians, of all Denominations [20]. Occom had observed the "great Engagedness, in these Colonies, to cultivate Psalmody," and he felt compelled to encourage "the Duty of Christians to learn the Songs of Zion.” Drawing largely from the writings of the Apostle Paul, the Presbyterian cautioned that simply singing was not enough. Christians had "to sing with the Spirit" or otherwise, beautiful or not, "it is like the Sound of a musical Instrument without Life ([20], p. 3)." When properly performed "the Songs of Zion, when they are sung with the Spirit of the Gospel, are very comforting, refreshing, and edifying to the Children of God.” Further still, such singing was "pleasing to God, and destructive to the Kingdom of Satan.” This was his motivation, he explained, to collect "a Number of choice Hymns, Psalms, and spiritual Songs, from a Number of Authors of different Denominations of Christians, that every Christian may be suited.” He concluded his prefatory address with his hope that this collection of "cordial Hymns" would "comfort you in your weary Pilgrimage; I hope they will assist and strengthen you through the various Changes of this Life, till you all safely arrive in the general Assembly Above, and Church the First-Born, where you shall have no more need of these imperfect Hymns; but shall perfectly join the Songs of Moses and the Lamb ([20], p. 4).”

In 1787, the reverend George Duffield expressed similar sentiments on behalf of the Synod of New York and Philadelphia. As the elected clerk he crafted the prefatory address for their recommended version of the psalms [21]. Despite the numerous negative examples he could have drawn from to explain the ruling body's venture into psalmody, Duffield instead emphasized the benefits to 
spirituality the music could foster. It was well known "by the best judges of the sacred text," he wrote, "that the Book of Psalms, in its original dress is a collection of the most elevated and sublime Compositions that are to be found in any language.” Many translations, however, had encountered difficulties in both keeping the original "piety, dignity, and poetic excellence" and infusing "the bright discoveries of the Gospel." Duffield reassured that "this has been happily executed by the learned and pious Dr. Watts, and the Psalms which he omitted have been supplied by Mr. Barlow, nearly in the same spirit and stile." More than this, he claimed, the psalms "have been carefully altered, so as to render the Composition better adapted to the circumstances of Christians in every country.” According to the Presbyterian leadership, all Christians, not just Presbyterians, would benefit from these psalms as they encouraged "understanding and devotion, and thereby continue the elevation and improvement of the Christian temper ([21], p. iii).”

As the denomination worked more closely with other churches, a growing concern about doctrinal purity emerged. In some cases, instead of emphasizing their common Christianity while retaining their inherited doctrinal positions, the Presbyterians adopted the specific beliefs of the other churches. Once again the Presbyterian leadership relied on music. In a unique attempt to inspire, exhort and edify their members, the Presbytery of Charleston moved beyond the traditional boundaries of the psalms and compiled and published hymns for their "public and private worship ([22], p. 1).” Among the myriad of songs, there are clear efforts to reiterate key Reformed beliefs, such as: "The Divinity of the Son," "The Trinity,” “Acceptable Worship,” “The Natural Depravity of Man,” “The Necessity of a Saviour,” "The Influences of the Spirit Experienced," and "Submission to Fatherly Chastisements." Yet within their midst were hymns devoted to love and one in particular reveals the continued Presbyterian pursuit of interdenominationalism—Hymn 151 or "Christian Unity.”

1. Let party names no more

The Christian world o'erspread;

Gentile and Jew, and bond and free,

Are one in Christ their head.

2. Among the saints on earth

Let mutual love be found;

Heirs of the same inheritance,

With mutual blessings crown'd.

3. Let envy, child of hell,

Be banish'd far away;

Those should in strictest friendship dwell,

Who the same Lord obey.

4. Thus will the church below

Resemble that above;

Where streams of pleasure ever flow,

And ev'ry heart is love ([22], p. 123).

Although the ruling body wished to maintain the doctrinal integrity of the church they deemed it equally important to reaffirm their interdenominational hopes; these pursuits had to co-exist. 
The following year, in the swampy and remote Washington City the reverend John Campbell was called to supply the sermon that would precede a concert held in the newborn capital ([23], pp. 371-74). He accepted and welcomed the chance to engage a public audience that extended well beyond his typical congregation. Using James 5:13 as his scriptural basis, Campbell addressed the topic of "Sacred Music," and he began by applauding his audience. Those in attendance had "a divine warrant for the part you are to act on this occasion; and permit me to congratulate you on the propriety of your conduct in recognizing a law of Christianity." Washington City was filled with opportunities "for criminal festivity and mirth," but "you nobly chuse the more rational, but unfashionable, mode of expressing cheerfulness, by a course of harmonious praise to the King of Saints ([24], p. 4).” This Campbell noted, was one of the great dangers of music. Its divine origin meant it was powerful and while it could inspire "devotion and rapture," music could also be "forced to speak the language of guilty passion, and serve at the altar of impure love ([24], p. 11).” Still, this was not to be taken as a call to abolish music. The book of Revelations, Campbell stated, made their duties as Christians quite clear: "we have not only a representation of the church triumphant, celebrating the praise of her Redeemer, but also of the church on earth, taking up the joyful theme, and imitating her jubilant strains; so that it is impossible for us to mistake our duty when we have such illustrious models, and so plain an example for our imitation.” As for the dangers of abuse, godly music held a solution in that it "possesses a surprising power over that black groupe of depraved passions that agitate the breast of man: Malice, envy, rage, anger, and a thirst of revenge, those demons that ravage the empire of the heart, and aim at desolating the globe, die away before the sacred magic of sound ([24], pp. 23 and 21).”

Like Samson Occom before him, Campbell was delighted in the revival of sacred music that he witnessed among Americans. However, the minister warned, this zeal needed to be tempered with knowledge and so he appealed to "the Apostle's conclusion, 'I will sing with the spirit, and I will sing with understanding also ([24], p. 24)." "Musical sounds” Campbell noted, "should breathe the same passionate language with the poetry, paint the same scenes and passions, and in short, echo its very spirit to the soul; but this will never be done by the spruce sopperies, and laboured conceits, of the fashionable music. Nothing can be more improper, than the introduction of such compositions into the harmony of the church ([24], p. 31)." As a counterpoint to this modern distraction, he presented the ancient Israelites whose harmony "was less complex than ours; its combinations were more simple and artless; and its expression more lively, forcible, and passionate. Theirs was the harmony of nature; ours is that of art." The Israelites also served as a caution against a popular holdover from an illiterate age, the practice of "lining out." As Campbell lamented, this was "when the whole service is interrupted till the chief musician reads, or rather doefully cants, out the line," but "what edification can be expected?" Both extremes had to be avoided, because they tended to "insult God, and are unprofitable to yourselves." As simple as the Israelite harmonies were, they fostered rather than impeded the glorification of God and the fortification of fellow believers, Campbell observed, by "lighting up a flame of sacred passion in the soul ([24], pp. 16 and 37).”

5 Campbell continues to assault modern musical novelties, such as "fugueing tunes," that were being introduced to divine worship. He states bluntly, “that man’s taste must be strangely depraved, who can relish the performance.” In them, he claimed, "no attention is paid to emphasis, cadence, or pronunciation; the ear is cloyed with endless repetition, or confused by a crowed of different words or sentences, assailing it at once.” Found on page 30. 
Among other things, the stories of John P. Campbell and the Presbytery of Charleston illustrate that by the beginning of the nineteenth century many Presbyterians were moving away from the exclusive use of psalms during corporate worship. Whether this was a result of the ruling body's consistent claim that all orthodox psalms were permissible is unclear. But what is clear is that the Presbyterians embraced hymns and spiritual songs in their churches with the same spirit that had shaped their psalmody. As Jonathan Freeman told the Hudson Presbytery in September of 1801, Christians must "sing unto the Lord a new song ([25], p. 9)." The minister was quick to note that he did not wish to abolish the psalms, because they were "in a remote sense, the word of Christ." However, Freeman argued that Christians should also "celebrate the praises of God in psalms and hymns and spiritual songs which are derived from the gospel of Christ." It only made sense, Freeman contended, "We preach Christ crucified, we pray in his name, and Christ should be the theme of our spiritual songs ([25], pp. 5, 16).” No element of public worship was to exclude Christ.

Although he was convinced that his fellow Presbyterians needed to seriously consider adopting both the psalms and hymns of Dr. Watts, he did not assume the solution would be best for all Christians. Keeping with the Presbyterian traditions of interdenominationalism, Christian edification, and Christian liberty, he told the ruling body, "We have no authority to meddle with any church out of our own bounds. They have a right to adopt any version they judge expedient. And if every denomination of Christians would pursue this line of conduct, there would not be so many disputes, and divisions among the professed disciples of Christ ([25], p. 26)." Strikingly similar to the language used by synods and assemblies past, Freeman reveals the continued embodiment of those beliefs. To that end, he hoped that his audience, both reading and listening, would not "be led, by the inchanted chord of implicit faith, to embrace what I have advanced upon this subject." Instead, he called them to challenge his opinion and "if other Christians differ, in judgment from me, I have no objection. Let every one act agreeably to scripture, and the dictates of an enlightened, unprejudiced, and good conscience." His sermon, he concluded, was offered for the same reason he suggested a more robust system of worship songs, "to promote his [Christ’s] glory and spiritual kingdom ([25], p. 30).”

In 1802, the Presbyterian General Assembly adopted a system of psalmody and hymnody edited and revised by the Congregationalist Timothy Dwight ([15], p. 182). This interdenominational venture combined the psalms of Dr. Watts with those of Dwight and even included hymns collected from the various corners of Christendom which were written by those who appreciated "the sacred magic of sound.” Although this decision was warmly welcomed by Presbyterians such as Freeman, Campbell and Occom, and it resembled the efforts made by the more democratically oriented churches in their midst, it should not be viewed as a moment of transformation for the Presbyterian Church into the ranks of the "religious newcomers." Recent scholarship has correctly contended that the Presbyterians were not enticed by experimentations with egalitarianism, and as a result the "sectarian" category does not fit the church well. The same is true for the traditional "establishmentarian" grouping as the Presbyterian story is more complex than that of a reactionary hegemonic power desperate to maintain control. Relying on the arguments of contemporary theologians, a fresh examination of the Presbyterian experience with psalmody and hymnody reveals a more nuanced Christianity that embraced both spirituality and theological integrity. The subsequent view of eighteenth-century American Presbyterians is one of Christians nurturing their faith through singing, struggling to strengthen the bonds between denominations, respecting Christian liberty in and outside of their church, and preserving 
orthodoxy. For the Presbyterians, at least, this story illustrates that the familiar historical "establishmentarian/sectarian" model will not suffice, and it strongly suggests a re-examination of the paradigm altogether.

\section{Conflicts of Interest}

The author declares no conflict of interest.

\section{References and Notes}

1. Presbytery of Transylvania. A Narrative of Mr. Adam Rankin's Trial, and remarks on the same, with some observation on his vindication; and a concluding address to Professors of the Presbyterian Denomination. Lexington, Kentucky: W. Maxwell \& Co., 1793.

2. C.S. Lewis. Surprised By Joy: The Shape of My Early Life. Orlando: Harcourt, Inc., 1955.

3. Alister E. McGrath. Christian Spirituality: An Introduction. Malden, MA: Blackwell Publishing, 2005.

4. J.I. Packer. “An introduction to systematic spirituality.” Crux 26, no. 1 (1990): 2-8.

5. Richard E. Averbeck. "Spirit, community, and mission: A biblical theology for spiritual formation.” Journal of Spiritual Formation \& Soul Care 1, no. 1 (2008): 27-53.

6. Sandra Schneiders. “Theology and spirituality: Strangers, rivals or partners?” Horizons 13 (1986): 253-74.

7. Fred Hood. Reformed America: The Middle and Southern States, 1783-1837. Tuscaloosa: University of Alabama Press, 1980.

8. Jon Butler. Awash in a Sea of Faith; Christianizing the American People. Cambridge, MA: Harvard University Press, 1990.

9. Nathan Hatch. Democratization of American Christianity. New Haven: Yale University Press, 1989.

10. Richard J. Mouw, and Mark A. Noll, eds. Wonderful Words of Life: Hymns in American Protestant History and Theology. Grand Rapids, MI: William B. Eerdmans Publishing Company, 2004.

11. Stephen A. Marini. Sacred Song in America: Religion, Music, and Public Culture. Urbana: University of Illinois Press, 2003.

12. George Pullen Jackson. White and Negro Spirituals: Their Life Span and Kinship. New York: Da Capo Press, 1975.

13. Presbyterian General Assembly. Records of the Presbyterian Church in the United States of America, 1706-1788. Philadelphia: Presbyterian Board of Publication, 1904.

14. Westminster Divines. The Humble Advice of the Assembly of Divines, Now by Authority of Parliament sitting at Westminster, Concerning a Confession of Faith: With Quotations and Texts of Scripture annexed. Presented by them lately to both Houses of Parliament. Edinburgh: Reprinted by Evan Tyler, 1647. Found in Princeton Theological Seminary Internet Archive. Available online: http://ia700301.us.archive.org/28/items/humbleadviceofas00west/ humbleadviceofas00west.pdf (accessed on 1 December 2013). 
15. Samuel J. Baird, ed. A Collection of the Acts, Devliverances, and Testimonies of the Supreme Judicatory of the Presbyterian Church from its Origin in America to the Present Time. Philadelphia: Presbyterian Board of Publication, 1856.

16. J.C.D. Clark. The Language of Liberty, 1660-1832; Political Discourse and Social Dynamics in the Anglo-American World. New York: Cambridge University Press, 1994.

17. James B. Bell. A War of Religion: Dissenters, Anglicans, and the American Revolution. New York: Palgrave MacMillan, 2008.

18. James Hastings Nichols. Corporate Worship in the Reformed Tradition. Philadelphia: Westminster Press, 1968.

19. Samuel Buell. The excellence and importance of the saving knowledge of the Lord Jesus Christ in the Gospel-preacher, plainly and seriously represented and enforced: and Christ preached to the gentiles in obedience to the call of God. A sermon, preached at East-Hampton, August 29, 1759; at the ordination of Mr. Samson Occum [i.e., Occom], a missionary among the Indians. By Samuel Buell, M.A. Pastor of the Church of Christ, at East-Hampton, Long-Island. To which is prefixed, a letter to the Rev. Mr. David Bostwick, Minister of the Presbyterian Church, in NewYork, giving some account of Mr. Occum's [sic] education, character, \&c. New York: James Parker and Company, 1761.

20. Samson Occom. A Choice Collection of Hymns and Spiritual Songs; Intended for the Edification of Sincere Christians, of all Denominations. New London: Timothy Green, 1774.

21. George Duffield, ed. Psalms Carefully Suited to the Christian Worship in the United States of America. Being an Improvement of the Old Versions of the Psalms of David. Allowed by the reverend Synod of New-York and Philadelphia, to be used in churches and private families. Philadelphia: Francis Bailey, 1787.

22. Presbytery of Charleston. A Collection of Hymns for Public and Private Worship, Approved of by the Presbytery of Charleston. Charleston, South Carolina: J. M’Iver, 1796.

23. Walter A. McDougall. Freedom Just Around the Corner: A New American History, 1585-1828. New York: Harper Perennial, 2005.

24. John P. Campbell. Sermon on Sacred Music: Preached before a Public Concert in Washington. Washington: Press of Hunter and Beaumont, 1797.

25. Jonathan Freeman. A Discourse on Psalmody. Delivered at Newburgh, before the Presbytery of Hudson, September, 1801. Newburgh: Dennis Coles, 1801.

(C) 2013 by the author; licensee MDPI, Basel, Switzerland. This article is an open access article distributed under the terms and conditions of the Creative Commons Attribution license (http://creativecommons.org/licenses/by/3.0/). 